\title{
A Status and Perceived Attitude Towards Child Abuse Among Upper Primary Students
}

\author{
Vidyanand S. Khandagale* and Rajendra Chavan \\ Department of Education, Shivaji University, Kolhapur, Maharashtra-416004, India \\ Email: vidyanandkhandagale@gmail.com*,rajendrachavan1@gmail.com
}

\section{ARTICLE INFORMATION}

Received: June 07, 2019

Revised: July 25, 2019

Accepted: August 23, 2019

Published Online: September 04, 2019

\section{Keywords:}

Status, Perceived attitude, Child Abuse, Upper Primary School Students

\begin{abstract}
Child abuse impedes an individual personality and leaves mark on the heart of an individual eventually and affects the growth and development. The children are most vulnerable and can be easily exploits. Child Abuse refers to the action which hurt or harms children in terms physical, emotional, sexual etc. The study was intended to find out the status and perceived attitude towards the child abuse among upper primary school students of Kolhapur city. A descriptive survey was conducted and the data was collected from 221 Upper Primary School students using structured questionnaire of child abuse. The findings of study were parents do not talk about the uncomfortable situations their child might face in absence of them along with and let the child make it know about the uncomfortable situation faced by their child to the responsible adult and the child to deal with such situations at school, movie, by doctor, friend or at a workshop. This is serious concern as parents must make aware about child abuse among their wards and Most of the Boys and Girls don't know what to do if they will have to face any of the above mentioned situations.
\end{abstract}

\section{Introduction}

Child abuse may sometime occur knowingly \& unknowingly by the parent or caregivers because of victims of various reasons but it severely affects the personality which gradually makes him/her difficult to adjust and have peaceful life. The abuse child personality get shackle, eventually repress and destroy the innate capabilities of human. When child in injured, emotional harm or have risk of severe harm then the child is in the phase of abuse. The forms of child abuse are physical, sexual, emotional, maltreatment and exploitation. The attitude towards child abuse reveals the socialization and awareness of the contextual society. Habetha et al. (2012) concluded that the forms of child abuse are physical, sexual, emotional and neglect. The abuse in any form gives victim a traumatizing lifetime experience. Deveney (2008) asserts that the consequences of child abuse are worst where it is unnoticed and has been for longer period of time in the society.

\section{Review of Literature}

India is home to over $19 \%$ of the world's children, making it the country with the largest child population in the world. Child abuse is a serious and widespread problem in India, as it is in many parts of the world today. World Health Organization given four types of child abuse: physical abuse, sexual abuse, emotional or psychological abuse and neglect (WHO, 2002). 109 children were sexually abused every day in India (NCRB, 2018). International studies revealed that $20 \%$ of women and $5-10 \%$ men report being sexually abuse as children, while $20-25 \%$ of all children report being physically abused (WHO, 2014). Overall crimes against children has increased steeply over six times in the decade over 2008-2018 from 22,500 cases recorded in 2008 to $1,41,764$ cases in 2018 (NCRB, 2018). The study conducted about child abuse in India by Ministry of Women \&amp; Child Development, Government of India reported that physical abuse was found in $69 \%$ of child respondents, sexual abuse in $53 \%$ children respondents, and emotional abuse in $48 \%$ children (MWCD, GOI, 2005). 
A more recent study by the National Commission for Protection of Child Rights conducted survey amongst 6632 children respondents in 7 states in India, revealed 99\% children face corporal punishment in schools (NCPCR, 2007). In one study girls respondents reports higher incidents of child sexual abuse; whereas boys respondents reports more physical and psychological abuse (Oates, 2013). In the medical point of view, doctors or dentists played important role in identification of child abuse in children. Research study showed that, $60-75 \%$ child abuse victims present with head, face and mouth injuries (Cairns et al., 2005). In the study of Knowledge and awareness of child abuse and neglect among children in Pondicherry, it is found that Majority of the children were aware of the acts constituting child abuse and neglect. A positive correlation was found between the age of children and awareness of child abuse and neglect. Furthermore, the girls had better knowledge about child abuse and neglect when compared to boys (Stephen, Krishnan, Pinni \& Moses, 2019).

In the primary teachers point view, the study about gender based teachers awareness about child abuse and neglect, it is found that few Primary School teachers are unaware about POCSO Act \& Few of Male \& Female teachers unaware of Case Identification \& Reporting of Child abuse and neglect (Khandagale \& Chavan, 2019). The study, conducted in Kolkata for examined characteristics of sexually trafficked children. The authors stated that these children experienced a host of mental, physical, and social challenges. Specifically, depression, loss of interest in daily living, and loneliness were noted (Chatterjee, Chakraborty, Srivastava \& Deb, 2006).

When the literature is critically reviewed it is observed that there is large number of child population in India is vulnerable to abuse, exploitation and neglect. The review of research and literature alarms that the cases and incidences of child abuse are increasing in Indian context. The very first stage to prevent the child abuse is to recognize the status and perceived attitude about child abuse among school students. The previous literature of researchers had suggested and recommended that it's an urgent need to identify the present status and perceived attitude of children about child abuse in the society. Various studies around the globe and In India revealed the consequences of child abuse in the children and eventually the long lasting effect. Hence in the present study an attempt has been made to study the status and analyze the child abuse among the upper Primary school students of Kolhapur city.

\section{Rationale of the Study}

Child abuse is curse or stigma in the human society. The effect of child abuse has long lasting and creates dysfunctional personality. The child abuse has an infiltration effect as an individual perceived relationship, socialization process which gradually reflected in an individual personality. A well round develop individual is an asset to the society and human being. Hence, child abuse has to be identified and prevented at right time and systematic manner which will mitigate the inhumane consequences.

\section{Research Questions}

1) Are the school students aware about the perception of concept of child abuse? If yes to what level/extent?

2) Is there gender difference in awareness of concept of child abuse among school students?

The researchers took keen interest in seeking the solutions of the above cited problem in the form of the following topic titled "A Status and Perceived Attitude towards Child Abuse among Upper Primary Students".

\section{Terms and Phrases used in the study}

\section{Child Abuse}

Child Abuse and Neglect is referred as uncomfortable by i) by looking or touching private parts of body ii) asking to undress iii) making uncomfortable by showing the child's his/her private parts, staring by wrong intention.

\section{Upper Primary Students}

Kothari commission suggested $10+2+3$ common educational structure. In 10 years again consists of $5+3+2$ common educational structure. The 5 years consists as (pre primary i.e. I to $\mathrm{V}$ ) and next 3 years consists as upper primary classes i.e. VI to VIII.

(Kothari Commission, 1964)

\section{Perceived Attitude About Child Abuse}

It refers to the various situation of making uncomfortable to the child and his/ her inclination towards it by the response or reaction. 


\section{Awareness:}

The present study awareness of child abuse refers to mentioning/talking about the uncomfortable situations and or dealing with the situations reference to child abuse.

\section{Objectives of the Study}

1) To find out the status of child abuse among upper primary school students.

2) To find out the gender based status about child abuse among upper primary school students.

3) To identify the perceived attitude towards the concept of child abuse among upper primary school students.

4) To identify the gender based perceived attitude about concept of child abuse among upper primary school students.

\section{Assumptions of the Study}

Upper primary students are aware of the concept of child abuse

\section{Research Design}

\subsection{Research Method \& Sample of the Study}

To achieve the objective of the study Researchers found Descriptive survey method more appropriate. The sample of the study was 221 upper primary school students $(\mathrm{N}=221)$ of Kolhapur city studying in State Board of Maharashtra in English Medium School

\subsection{Sampling Method}

The purposive incidental sampling method was used to collect the data form upper primary school students in the Kolhapur city.

\subsection{Instrument Used for the Study}

Researchermade-Structured 'ChildAbuseQuestionnaire' was prepared and implied. The questionnaire comprise of three parts. Part-I consists 'Personal profile of students', Part-II consists of Eleven statements on child abuse having each three options 'Yes', 'No' \& 'I don't know' and Part-III having Ten statements on Child Abuse Awareness consists of three options as 'Agree', Disagree' $\&$ 'I don't know'.

\subsection{Statistical Analysis}

The data was analyzed and interpreted by using 'Percentage' technique.

\section{Data Analysis and Interpretation}

Table 1: Status and Awareness of Child Abuse Among Upper Primary School Students.

\begin{tabular}{|c|c|c|c|c|}
\hline $\begin{array}{l}\text { Sr. } \\
\text { No. }\end{array}$ & Statements & $\begin{array}{l}\% \text { of } \\
\text { Yes }\end{array}$ & $\begin{array}{l}\% \\
\text { of } \\
\text { No }\end{array}$ & $\begin{array}{l}\% \text { of } \\
\text { I don't } \\
\text { Know }\end{array}$ \\
\hline 1 & $\begin{array}{l}\text { Has anyone ever made you } \\
\text { uncomfortable by trying to look } \\
\text { at any of the private parts of } \\
\text { your body }\end{array}$ & 16 & 75 & 9 \\
\hline 2 & $\begin{array}{l}\text { Has anyone ever made you } \\
\text { uncomfortable by trying to } \\
\text { touch any of the private parts of } \\
\text { your body }\end{array}$ & 8 & 86 & 6 \\
\hline 3 & $\begin{array}{l}\text { Has anyone ever made you } \\
\text { uncomfortable by showing you } \\
\text { his/her private parts }\end{array}$ & 6.5 & 88.5 & 5 \\
\hline 4 & $\begin{array}{l}\text { Has anyone ever made you } \\
\text { uncomfortable by asking you to } \\
\text { undress in the absence/presence } \\
\text { of your elders }\end{array}$ & 7 & 88 & 5 \\
\hline 5 & $\begin{array}{l}\text { Do you know or have you heard } \\
\text { of any other youngster who has } \\
\text { experienced any of the above } \\
\text { situations and has spoken to you } \\
\text { about it }\end{array}$ & 18 & 74.5 & 7.5 \\
\hline 6 & $\begin{array}{l}\text { Have your parents ever talked } \\
\text { with you about the above } \\
\text { mentioned situations? }\end{array}$ & 26.5 & 61.5 & 12 \\
\hline 7 & $\begin{array}{l}\text { Did they explain that the above } \\
\text { mentioned situations can be } \\
\text { faced by you in their absence / } \\
\text { presence }\end{array}$ & 16 & 74.5 & 9.5 \\
\hline 8 & $\begin{array}{l}\text { Did they tell you to let a } \\
\text { responsible adult know if any } \\
\text { of the above situations are faced } \\
\text { by you? }\end{array}$ & 26.5 & 65 & 8.5 \\
\hline 9 & $\begin{array}{l}\text { Were you ever told about how } \\
\text { to deal with such situations } \\
\text { at school, or in a movie or by } \\
\text { a doctor or a friend or at a } \\
\text { workshop? }\end{array}$ & 22 & 70 & 18 \\
\hline 10 & $\begin{array}{l}\text { Do you think that someone very } \\
\text { close to you like say a friend, a } \\
\text { family member or a relative can } \\
\text { make you feel uncomfortable } \\
\text { in any of the above mentioned } \\
\text { ways? }\end{array}$ & 9.5 & 76.5 & 14 \\
\hline 11 & $\begin{array}{l}\text { Do you know what to do if } \\
\text { you will have to face any of the } \\
\text { above mentioned situations? }\end{array}$ & 29.5 & 62 & 8.5 \\
\hline
\end{tabular}




\section{Observations and Interpretations}

From the observation of the Table $1 \&$ Graph 1, It is interpreted that, among the total sample of Upper Primary School students:

1) Most of the (75\%) students have been never made uncomfortable by trying to look at any of the private parts of their body. Few of them (16\%) have been made uncomfortable and Very Few (9\%) students are unaware of it.

2) Majority of the (86\%) students have been never made uncomfortable by trying to touch at any of the private parts of their body. Few of them (8\%) have been made uncomfortable and $(6 \%)$ students are unaware of it.

3) Majority of the $(88.5 \%)$ students have been never made uncomfortable by showing his/her private parts. Few of them (6.5\%) have been made uncomfortable and (5\%) students are unaware of it.

4) Majority of the (88\%) students have been never made uncomfortable by asking to them to absence/ presence of their elders. Few of them (7\%) have been made uncomfortable and Very Few (5\%) students are unaware of it.

5) Most of the (74.5\%) students have never heard of any other youngster who has experienced any of uncomfortable situations and has spoken to them about it'. Few of them (18\%) have been heard about it and Very Few (7.5\%) students are unaware of it.

6) Most of the (61.5\%) students' parents have never talked about the mentioned situations making them uncomfortable. Wherein Few of the (26.5\%) parents have mentioned uncomfortable situations and Very Few (12\%) does not talked about it.

7) Most of the (74.5\%) parents did not spoke about the uncomfortable situation can be faced by their child in their absence, wherein Few of the (16\%) parents mentioned of the situation and Very Few $(9.05 \%)$ are unaware of it.

8) Most of the (65\%) parents did not tell their child to let know about the uncomfortable situation faced by their child to the responsible adult. Wherein, Few (26.5\%) have been told and Very Few (8.5\%) of the students don't know about it.

9) Most of the (70\%) parents have did not told to their child to deal with such situations at school, movie, by doctor, friend or at a workshop. Wherein Few (22\%) parents told about dealing with such situation and Few (8\%) of students are unaware of it.

10) Most of the $(76.5 \%)$ students don't think that someone very close to them like friend, family member or relative can make them feel uncomfortable. Wherein Few (14\%) of students are not known and Very Few $(9.5 \%)$ think that someone close to them make them uncomfortable.

11) Most of the (62\%) students do not know what to do if they face such uncomfortable situation, wherein Few $(29.5 \%)$ students know to deal with such situation and Very Few (8.5\%) students don't know about it.

\section{Graph 1}

\section{Status and Awareness of Child Abuse Among Upper Primary School Students}

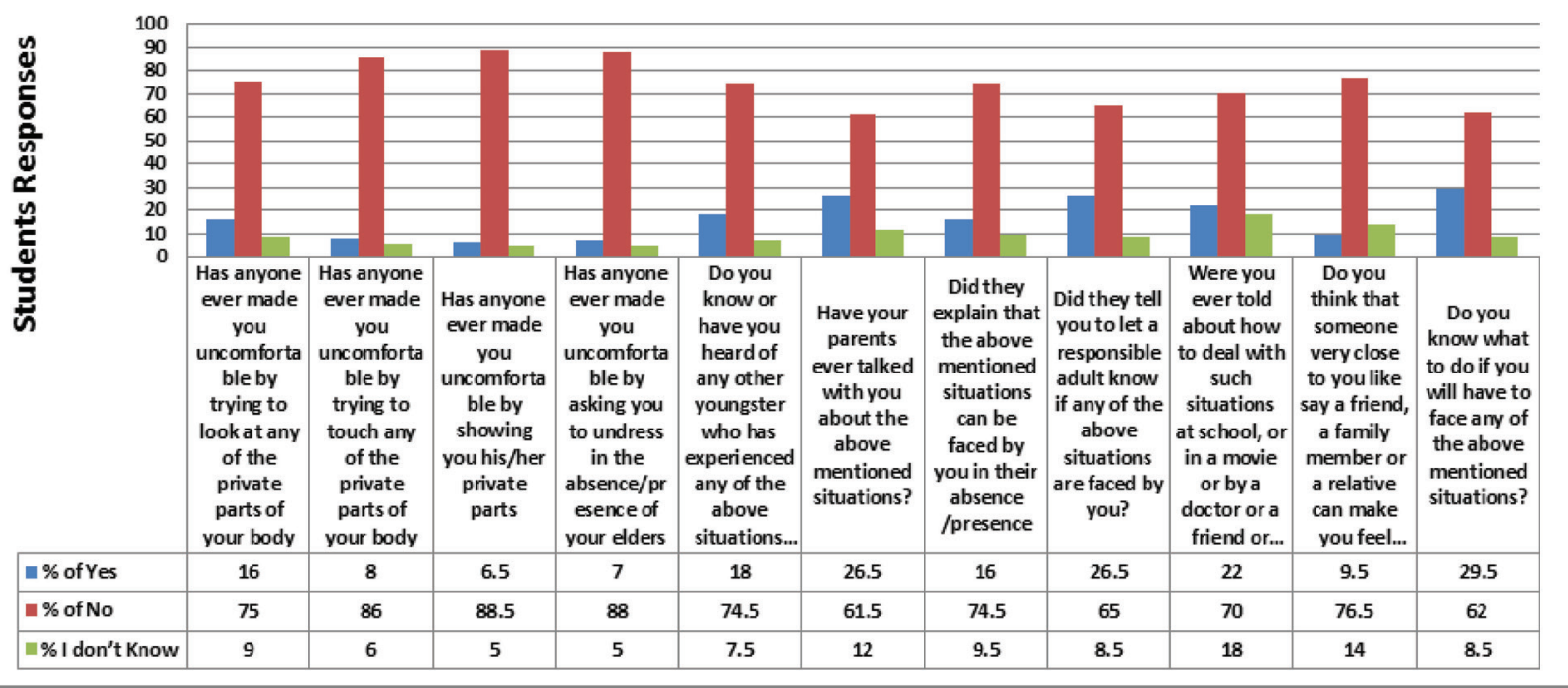


Table 2: Status and Awareness of Child Abuse Among Upper Primary School Students based on Gender.

\begin{tabular}{|c|c|c|c|c|c|c|c|}
\hline \multirow{2}{*}{$\begin{array}{l}\text { Sr. } \\
\text { No. }\end{array}$} & \multirow[t]{2}{*}{ Statements } & \multicolumn{3}{|l|}{ Boys } & \multicolumn{3}{|l|}{ Girls } \\
\hline & & $\begin{array}{l}\% \text { of } \\
\text { Yes }\end{array}$ & $\begin{array}{l}\% \text { of } \\
\text { No }\end{array}$ & $\begin{array}{l}\text { \% I don't } \\
\text { Know }\end{array}$ & $\begin{array}{l}\% \text { of } \\
\text { Yes }\end{array}$ & \begin{tabular}{l|}
$\%$ of \\
No
\end{tabular} & $\begin{array}{l}\text { \% I don't } \\
\text { Know }\end{array}$ \\
\hline 1 & $\begin{array}{l}\text { Has anyone ever made you uncomfortable by trying to look at any of the } \\
\text { private parts of your body }\end{array}$ & 3 & 95 & 2 & 17 & 70 & 13 \\
\hline 2 & $\begin{array}{l}\text { Has anyone ever made you uncomfortable by trying to touch any of the } \\
\text { private parts of your body }\end{array}$ & 7 & 89 & 4 & 16 & 69 & 14 \\
\hline 3 & $\begin{array}{l}\text { Has anyone ever made you uncomfortable by showing you his/her } \\
\text { private parts }\end{array}$ & 6 & 91 & 3 & 15 & 71 & 14 \\
\hline 4 & $\begin{array}{l}\text { Has anyone ever made you uncomfortable by asking you to undress in } \\
\text { the absence/presence of your elders }\end{array}$ & 5 & 90 & 5 & 17 & 69 & 14 \\
\hline 5 & $\begin{array}{l}\text { Do you know or have you heard of any other youngster who has } \\
\text { experienced any of the above situations and has spoken to you about it }\end{array}$ & 14 & 71 & 15 & 16 & 68 & 16 \\
\hline 6 & $\begin{array}{l}\text { Have your parents ever talked with you about the above mentioned } \\
\text { situations? }\end{array}$ & 26.5 & 61.5 & 12 & 27 & 65 & 9 \\
\hline 7 & $\begin{array}{l}\text { Did they explain that the above mentioned situations can be faced by } \\
\text { you in their absence / presence }\end{array}$ & 16 & 75 & 9 & 18 & 73 & 9 \\
\hline 8 & $\begin{array}{l}\text { Did they tell you to let a responsible adult know if any of the above } \\
\text { situations are faced by you? }\end{array}$ & 21.5 & 69 & 9.5 & 22 & 70 & 18 \\
\hline 9 & $\begin{array}{l}\text { Were you ever told about how to deal with such situations at school, or } \\
\text { in a movie or by a doctor or a friend or at a workshop? }\end{array}$ & 10 & 75.5 & 14.5 & 9.5 & 74 & 15.5 \\
\hline 10 & $\begin{array}{l}\text { Do you think that someone very close to you like say a friend, a family } \\
\text { member or a relative can make you feel uncomfortable in any of the } \\
\text { above mentioned ways? }\end{array}$ & 23 & 64 & 13 & 28 & 58 & 14 \\
\hline 11 & $\begin{array}{l}\text { Do you know what to do if you will have to face any of the above } \\
\text { mentioned situations? }\end{array}$ & 30 & 62 & 8 & 27 & 59 & 14 \\
\hline
\end{tabular}

\section{Graph 2}

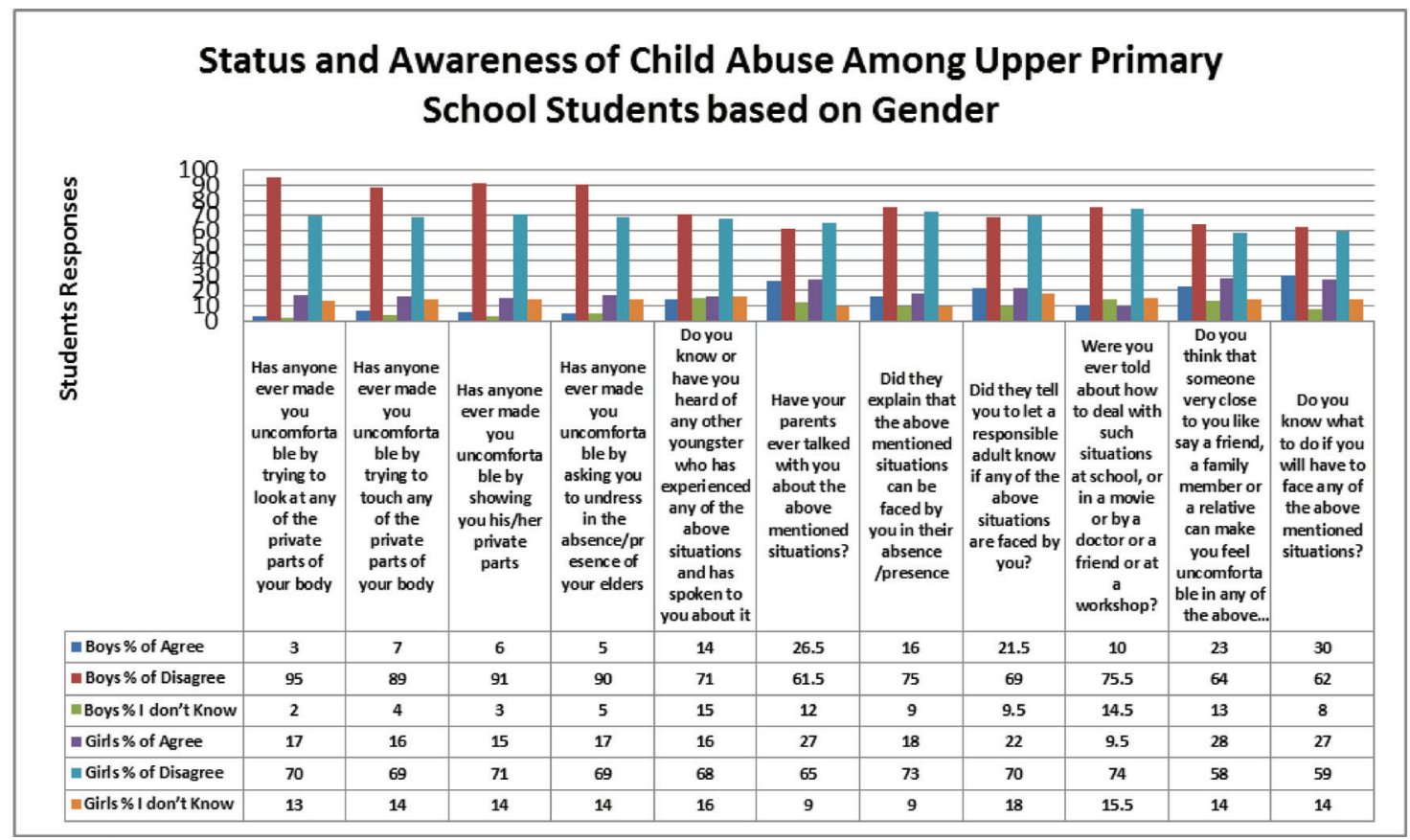




\section{Observation and Interpretation}

From the observation of the Table $2 \&$ Graph 2, it is interpreted that among total sample of Upper Primary School students:

1) Majority (89\%) Boys \& Most of the (70\%) Girls have been never made uncomfortable by trying to look at any of the private parts of their body.

2) Majority (95\%) Boys \& Most of the (69\%) Girls have been never made uncomfortable by trying to touch any of the private parts of their body.

3) Majority (91\%) Boys \& Most of the (71\%) Girls have been never made uncomfortable by showing his/her private parts'

4) Majority (90\%) Boys \& Most of the (69\%) Girls have been never made uncomfortable by asking them to undress in the absence/presence of their elders'

5) Most of the (71\%) Boys \& (68\%) Girls don't know or never heard of any other youngster who has experienced any of the uncomfortable situations and has spoken to them about it'.
6) Most of the (61.5\%) Boys \& (65\%) Girls, parents never talked with them about the uncomfortable situations.

7) Most of the (75\%) Boys \& Most of the (73\%) Girls have been not told that the uncomfortable situations can be faced by them in their absence/presence'.

8) Most of the (69\%) Boys \& (70\%) Girls are unaware of that the uncomfortable situation has to be told to the responsible adult.

9) Majority of the (75.5\%) Boys \& Most of the (74\%) Girls have been never told about how to deal with such situations at school, in a movie, by a doctor or a friend or at a workshop.

10) Most of the (64\%) Boys \& Most of the (58\%) Girls have been never thought that someone very close to them (like say a friend, a family member or a relative) can make you feel uncomfortable.

11) Most of the (62\%) Boys \& Most of the (59\%) Girls don't know what to do if they will have to face any of the above mentioned situations.

Table 3: Perceived Attitude towards Child Abuse among Upper Primary School Students.

\begin{tabular}{|l|l|l|l|l|}
\hline $\begin{array}{l}\text { Sr. } \\
\text { No. }\end{array}$ & Statements & $\begin{array}{l}\text { \% of } \\
\text { Agree }\end{array}$ & $\begin{array}{l}\text { \% of } \\
\text { Disagree }\end{array}$ & $\begin{array}{l}\text { \% } \\
\text { I don't } \\
\text { Know }\end{array}$ \\
\hline 1 & If someone tries to make you uncomfortable, it is all your own fault. & 15.5 & 66 & 18.5 \\
\hline 2 & Boys don't have to worry about someone touching their private parts. & 12.5 & 62 & 25.5 \\
\hline 3 & If someone makes you feel uncomfortable, you should say a firm 'No' to that person. & 72 & 24.5 & 3.5 \\
\hline 4 & $\begin{array}{l}\text { If a grown-up tells you to do something and you find it inappropriate, but you still have } \\
\text { to do it }\end{array}$ & 16 & 67.5 & 16.5 \\
\hline 5 & $\begin{array}{l}\text { Some touches could be giving you a good feeling in the beginning, but may turn out to } \\
\text { be disturbing later on. }\end{array}$ & 36.5 & 32.5 & 31 \\
\hline 6 & If someone makes you feel uncomfortable, you should not tell about it to anyone. & 12 & 78 & 10 \\
\hline 7 & $\begin{array}{l}\text { Most people who make children uncomfortable do not belong to their families or are } \\
\text { total strangers }\end{array}$ & 33 & 28 & 39 \\
\hline 8 & $\begin{array}{l}\text { Children can be made to feel uncomfortable only when they are alone or are outside their } \\
\text { house. }\end{array}$ & 39.5 & 33.5 & 27 \\
\hline 9 & Only girls are made to feel uncomfortable. & 18.5 & 67 \\
\hline 10 & $\begin{array}{l}\text { Children from well-known or rich families do not have to face any of the above } \\
\text { situations. }\end{array}$ & 12.5 & 52.5 & 35 \\
\hline
\end{tabular}

\section{Observation and Interpretation:}

From the observations of Table 3 and Graph 3, it is interpreted that, Among the total sample of Upper Primary School students:

1) Most of (66\%) 'disagree' Few (15\%) 'Agree', Few (18.5\%) students responded 'don't know' 'If someone tries to make you uncomfortable, it is your own entire fault.
2) Most of (62\%) 'disagree', Very few (12.5\%) 'Agree', Few $(25.5 \%)$ students responded 'don't know' for 'Boys don't have to worry about someone touching their private parts'.

3) Most of (72\%) 'agree' Few (3.5\%) 'don't know', very few $(24.5 \%)$ students responded 'disagree', 'If someone makes you feel uncomfortable, you should say a firm 'No' to that person, 
4) Most of (67.5\%) 'disagree' Few (16\%) 'Agree', (16.5\%) students responded 'don't know', 'If a grown-up tells you to do something and you find it inappropriate, but you still have to do it',

5) Moderate (36.5\%) 'Agree' (31\%) 'don't know', (32.5\%) students responded 'disagree' for 'Some touches could be giving you a good feeling in the beginning, but may turn out to be disturbing later on'.

6) Most of (78\%) 'disagree' Few (10\%) 'don't know', Few (12\%) students responded 'Agree', 'If someone makes you feel uncomfortable, you should not tell about it to anyone',

7) Moderate (39\%) 'don't know' (28\%) 'disagree', (33\%) students responded 'agree' for 'Most people who make children uncomfortable do not belong to their families or are total strangers',

8) Moderate (39.5\%) 'agree' Few (27\%) 'don't know', (33.5\%) students responded 'disagree', for 'Children can be made to feel uncomfortable only when they are alone or are outside their house'

9) Most of (67\%) 'disagree' (14.5\%) 'don't know', Few $(18.5 \%)$ students responded 'agree', for 'Only girls are made to feel uncomfortable',

10) Moderate of the (52.5\%) 'disagree' Few (12.5\%) 'agree' (35\%) students responded that they 'don't know' about the 'Children from well-known or rich families do not have to face any of the above situations'

\section{Graph 3}

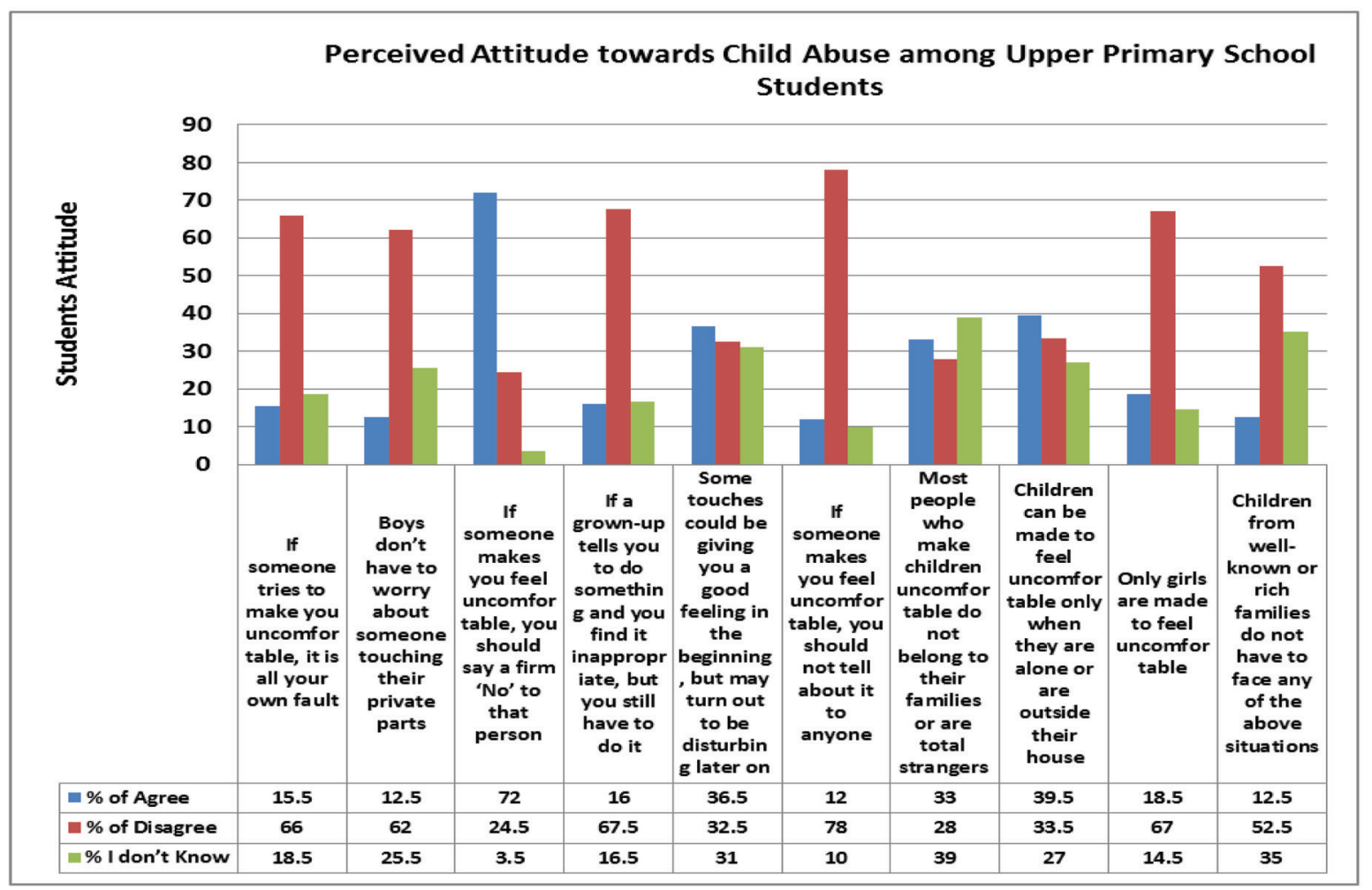

Table 4: Perceived Attitude towards Child Abuse among Upper Primary School Students based Gender.

\begin{tabular}{|c|c|c|c|c|c|c|c|}
\hline \multirow{2}{*}{$\begin{array}{l}\text { Sr. } \\
\text { No. }\end{array}$} & \multirow[t]{2}{*}{ Statements } & \multicolumn{3}{|l|}{ Boys } & \multicolumn{3}{|l|}{ Girls } \\
\hline & & $\begin{array}{l}\% \text { of } \\
\text { Agree }\end{array}$ & $\begin{array}{l}\% \text { of } \\
\text { Disagree }\end{array}$ & $\begin{array}{l}\% \\
\text { I don't } \\
\text { Know }\end{array}$ & $\begin{array}{l}\% \text { of } \\
\text { Agree }\end{array}$ & $\begin{array}{l}\% \text { of } \\
\text { Disagree }\end{array}$ & $\begin{array}{l}\text { \% } \\
\text { I don't } \\
\text { Know }\end{array}$ \\
\hline 1 & $\begin{array}{l}\text { If someone tries to make you uncomfortable, it is your } \\
\text { own entire fault. }\end{array}$ & 10 & 74.5 & 14.5 & 18.5 & 69.5 & 12 \\
\hline 2 & $\begin{array}{l}\text { Boys don't have to worry about someone touching their } \\
\text { private parts. }\end{array}$ & 18 & 69.5 & 12.5 & 21 & 60 & 19 \\
\hline
\end{tabular}




\begin{tabular}{|l|l|l|l|l|l|l|l|}
\hline 3 & $\begin{array}{l}\text { If someone makes you feel uncomfortable, you should say } \\
\text { a firm 'No' to that person. }\end{array}$ & 80 & 17.5 & 2.5 & 91 & 6 & 3 \\
\hline 4 & $\begin{array}{l}\text { If a grown-up tells you to do something and you find it } \\
\text { inappropriate, but you still have to do it }\end{array}$ & 17 & 66.5 & 16.5 & 15 & 70.5 & 14.5 \\
\hline 5 & $\begin{array}{l}\text { Some touches could be giving you a good feeling in the } \\
\text { beginning, but may turn out to be disturbing later on. }\end{array}$ & 31 & 39.5 & 29.5 & 42.5 & 31.5 & 26 \\
\hline 6 & $\begin{array}{l}\text { If someone makes you feel uncomfortable, you should not } \\
\text { tell about it to anyone. }\end{array}$ & 9 & 79 & 12 & 18 & 64 & 18 \\
\hline 7 & $\begin{array}{l}\text { Most people who make children uncomfortable do not } \\
\text { belong to their families or are total strangers }\end{array}$ & 33 & 28 & 39 & 34.5 & 30.5 & 35 \\
\hline 8 & $\begin{array}{l}\text { Children can be made to feel uncomfortable only when } \\
\text { they are alone or are outside their house. }\end{array}$ & 39.5 & 33.5 & 27 & 41.5 & 24.5 & 25 \\
\hline 9 & Only girls are made to feel uncomfortable. & 30.5 & 57 & 22.5 & 51.5 & 30 & 18.5 \\
\hline 10 & $\begin{array}{l}\text { Children from well-known or rich families do not have to } \\
\text { face any of the above situations. }\end{array}$ & 18.5 & 52.5 & 29.5 & 33.5 & 61.5 & 5 \\
\hline
\end{tabular}

\section{Graph 4}

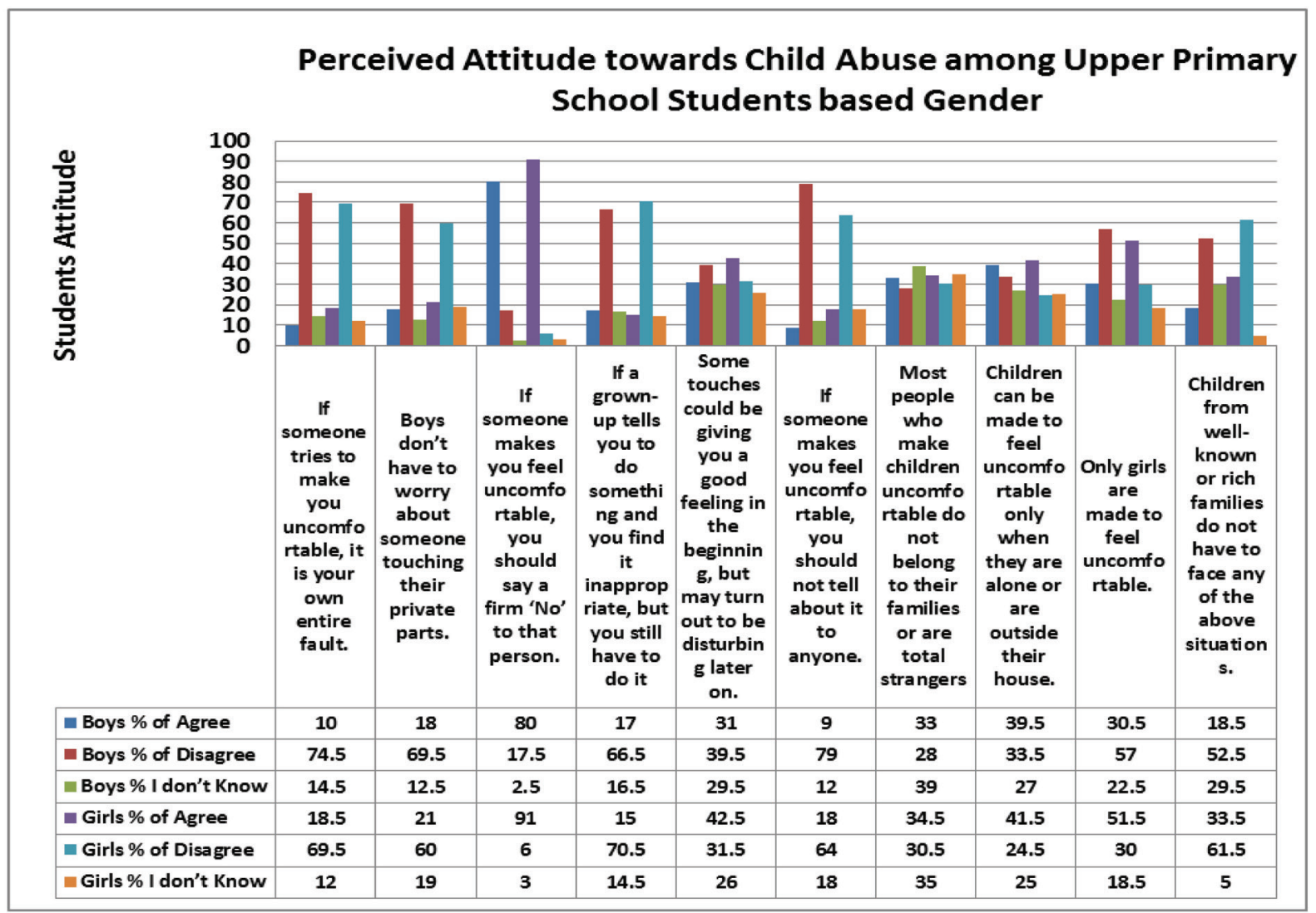

\section{Observation and Interpretation}

From the observation of the Table 4 and Graph 4 , it is interpreted that, among total sample of Upper Primary School Students:
1) Most of the (74.5\%) Boys \& (69.5\%) Girls 'Disagree' for 'it is their entire fault, If someone tries to make them uncomfortable, 
2) Most of the (69.5\%) Boys \& Most of the (60\%) Girls 'Disagree' for the statement, 'Boys don't have to worry about someone touching their private parts'.

3) Majority of the (80\%) Boys \& (91\%) Girls 'Agree' to say firm 'No' to that person, If he makes them feel uncomfortable.'

4) Most of the (66.5\%) Boys \& (70.5\%) Girls 'Disagree' to do something inappropriate told by grown-ups.

5) The Moderate number of (39.5\%) Boys followed by $(31.5 \%)$ Girls 'Disagree' and Moderate Number of (31\%) Boys followed by (42.5\%) Girls 'Agree' for statement 'Some touches could be giving you a good feeling in the beginning, but may turn out to be disturbing later on'.

6) Moderate Number of (79\%) Boys \& (64\%) Girls 'Disagree' for the statement 'If someone makes you feel uncomfortable, you should not tell about it to anyone.'

7) Moderate number of (39\%) Boys \& (35\%) Girls are unaware that, Most people who make children uncomfortable do not belong to the families or are total strangers.

8) Moderate number of (39.5\%) Boys \& (41.5\%) Girls 'Agree' that Children can be made to feel uncomfortable only when they are alone or outside their house.

9) Moderate number of (57\%) Boys disagree for the statement 'Only girls are made to feel uncomfortable, wherein moderate number of (51.5\%) Girls agree.

10) Moderate number of (52.5\%) Boys \& (61.5\%) Girls disagree for the statement Children from well-known or rich families do not have to face any of the above situations.'

\section{Major Findings in Nutshell}

\section{a) Status and Awareness of Child Abuse Among Upper Primary School Students:}

- Most of the (74.5\%) parents did not spoke about the uncomfortable situation can be faced by their child in their absence, wherein Few of the (16\%) parents mentioned of the situation and Very few $(9.05 \%)$ are unaware of it.

- Most of the (65\%) parents did not tell their child to let know about the uncomfortable situation faced by their child to the responsible adult. Wherein, Few (26.5\%) have been told and very few (8.5\%) of the students don't know about it.

- Most of the (70\%) parents have did not told to their child to deal with such situations at school, movie, by doctor, friend or at a workshop Wherein Few (20\%) parents told about dealing with such situation and Few $(18 \%)$ of students are unaware of it.

\section{b) Status and Awareness of Child Abuse Among Upper Primary School Students Based on Gender:}

- Most of the (61.5\%) Boys \& (65\%) Girls, parents never talked with them about the uncomfortable situations.

- Most of the (75\%) Boys \& Most of the (73\%) Girls have been not told that the uncomfortable situations can be faced by them in their absence/presence'.

- Most of the (69\%) Boys \& (70\%) Girls) are unaware of that the uncomfortable situation has to be told to the responsible adult.

- Majority of the (75.5\%) Boys \& Most of the (74\%) Girls have been never told about how to deal with such situations at school, in a movie, by a doctor or a friend or at a workshop.

- Most of the (64\%) Boys \& Most of the (58\%) Girls have been never thought that someone very close to them (like say a friend, a family member or a relative) can make you feel uncomfortable.

- Most of the (62\%) Boys \& Most of the (59\%) Girls don't know what to do if they will have to face any of the above mentioned situations

\section{c) Perceived Attitude Towards Child Abuse Among Upper Primary School Students:}

- Moderate (36.5\%) 'Agree' (31\%) 'don't know', $(32.5 \%)$ students responded 'disagree' for 'Some touches could be giving you a good feeling in the beginning, but may turn out to be disturbing later on'.

- Moderate (39.5\%) 'agree' Few (27\%) 'don't know' (33.5\%) students responded 'disagree', for 'Children can be made to feel uncomfortable only when they are alone or are outside their house'

- Most of (67\%) 'disagree' (14.5\%) 'don't know', Few (18.5\%) students responded 'agree', for 'Only girls are made to feel uncomfortable'

\section{d) Perceived Attitude Towards Child Abuse Among Upper Primary School Students Based Gender:}

- Most of the (74.5\%) Boys \& (69.5\%) Girls 'Disagree' for 'it is their entire fault, If someone tries to make them uncomfortable,

- Most of the (69.5\%) Boys \& Most of the (60\%) Girls 'Disagree' for the statement, 'Boys don't have to worry about someone touching their private parts'.

- Moderate number of (57\%) Boys disagree for the statement 'Only girls are made to feel uncomfortable, wherein moderate number of (51.5\%) Girls agree. 


\section{Discussion}

The findings of the study reveal that parents do not talk about the uncomfortable situations their child might face in absence of them along with and let the child make it know about the uncomfortable situation faced by their child to the responsible adult and the child to deal with such situations at school, movie, by doctor, friend or at a workshop. This is serious concern as Parents must make aware about child abuse among their wards.

Most of the Boys \& Most of the Girls don't know what to do if they will have to face any of the above mentioned situations. The prevention and defense strategies need to be taught to the boys and girls. There is need of hour to orient and educate the students to know their child right and dealing with the situation.

Most of 'disagree' 'don't know', few students responded 'agree', for 'Only girls are made to feel uncomfortable'. Various researches reveal that not only girls but boys are also made uncomfortable. This is common notion in the society that only girls are made uncomfortable. Both of them should be taken care.

Most of the boys and girls agree that 'it is their entire fault, if someone tries to make them uncomfortable but still there students who feel so and unaware of.

Most of the Boys \& Most of the Girls 'Disagree' for , 'Boys don't have to worry about someone touching their private parts'. But few perceive like so and are unaware of. The reason might be the socialization of the children and their surroundings.

\section{Research Implication}

The findings of the study revealed that, the parents and child do not have interaction about uncomfortable situations, that may confronted by their ward. This is because of socialization \& closed society norms or a feeling of awkwardness to talk on such issues. There is need to get cognizance of such issues by the parents and have orientation or interactions about the different forms of abuse with their child. Gender does no matter Abuse may be done to boy or girl and it does affect to both the gender.

\section{Suggestions}

1. Orientation/workshops for school going children need to be conducted for the prevention and different strategies to confront the uncomfortable situations and identification of abuse to deal with.

2. School organization need take more initiatives to create social cohesion among boys and girls. So, as there would be no discrimination based on the gender and will learn respect own bodies as well as others.

3. Co-curricular and Extra-curricular activities need to be design such a way that school children should get sensitize and confident with self-esteem and respect to their own body and to orient that it's not their fault if somebody put them in uncomfortable situation.

\section{Acknowledgement}

This research was supported by ICSSR, New Delhi under Major Research Project. We are thankful to Students, Teachers and Administrators of Schools in Kolhapur City for allowing and cooperating for the data collection. We thank to our Mother Institution Shivaji University, Kolhapur for academic and administrative support.

\section{References}

Ali, M.I. (2018). Protection of Children from Sexual Abuse in Early Years Education in Pakistan: Challenges and Issues. Journal of Early Childhood Care and Education, 2, 113-134.

Cairns, A.M., Mok, J.Y., \& Welbury, R.R. (2005). Injuries to the Head, Face, Mouth and Neck in Physically Abused Children in a Community Setting. International Journal of Pediatric Dentistry, 15(5), 310-318. https:// doi.org/10.1111/j.1365-263X.2005.00661.x

Chatterjee P., Chakraborty, T., Srivastava, N., \& Deb, S. (2006). Short and Long-term Problems Faced by Trafficked Children: A Qualitative Study. Social Science International, 22(1), 167-182.

Devaney, J. (2008). Chronic child abuse and domestic violence. Children and families with long-term and complex needs. Child Family \& Social Work, 13(4), 443-453. https://doi.org/10.1111/j.13652206.2008.00559.x

Habetha, S., Bleich, S., Weidenhammer, J., \& Fegert, J.M. (2012). A prevalence-based approach to societal costs occurring in consequence of child abuse and neglect. Child and Adolescent Psychiatry and Mental Health, 6, 1-10. https://doi.org/10.1186/1753-2000-6-35 
Hynniewta, B., Jose, T.T., \& Anjali, K.G. (2017). Knowledge and attitude on child abuse among school teachers in selected urban English medium schools of Udupi District. Manipal Journal of Nursing and Health Sciences, 3(1), 32-36.

Khandagale, V.S. \& Chavan, R.L. (2019). Child Abuse and Neglect: Gender Based Teachers Awareness. International Journal of Indian Psychology, 7(3), 113-121.

Ministry of Women and Child Development, Government of India (2007). Study on Child Abuse: Government of India.

NCPCR (2007). Welcome to National Commission for Protection of Child Rights. Retrieved July 30, 2020, from https://www.ncpcr.gov.in/.

National Crime Records Bureau. (2018). OGD Platform: Open Data Source Government of India. Retrieved July 30, 2020, from https://ncrb.gov.in/sites/default/ files/Crime\%20in\%20India\%202018\%20-\%20 Volume\%201.pdf.

Oates R.K. (2013). Child Abuse as an International Issue: Cross-Cultural Perspectives. In: Krugman R., Korbin J. (eds) C. Henry Kempe: A 50 Year Legacy to the Field of Child Abuse and Neglect. Child Maltreatment (pp. 231-237). Springer, Dordrecht.

https://doi.org/10.1007/978-94-007-4084-6_28

Price, J.H., Islam, R., Gruhler, J., Dove, L., Knowles, J., \& Stults, G. (2001). Public Perceptions of Child Abuse and Neglect in a Midwestern Urban Community. Journal of Community Health, 26, 271-284.

https://doi.org/10.1023/A:1010356528082

Ramesh, G., Kumar, A., Raj, A, Gupta, B., Katiyar, A., \& Nagarajappa, R. (2017). Child Abuse and Neglect: A Survey on Primary School Teachers of Kanpur City. International Journal of Medical Toxicology and Forensic Medicine, 7(2), 105-116. https://doi.org/10.22037/ ijmtfm.v7i2(Spring). 13088

Stephen, S.S., Krishnan, G., Pinni, J. \& Moses, J. (2019). Knowledge and Awareness of Child Abuse and Neglect among Children in Pondicherry. International Journal of Forensic Odontology, 4(2), 50-53.

UN Convention on the Rights of the Child (With Optional Protocols). Retrieved March 05, 2019. Retrieved from http://www.unicef.org/crc

Vijayalakshmi, P., Pashapu, D.R., Kathyayani, B.V., Gandhi, S.L., El-Arousy, W., \& Math, S.B. (2016). Nursing students' knowledge of child abuse and neglect in India. British Journal of Nursing, 22(5), 264-268. https://doi.org/10.12968/bjon.2016.25.5.264

World Health Organization (2002). World report on violence and health. Geneva: World Health Organization.

World Health Organization (2014). Child maltreatment ("child abuse"). Geneva: World Health Organization.

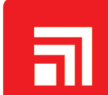 CHITKARA}

\section{Issues and Ideas in Education}

Chitkara University, Saraswati Kendra, SCO 160-161, Sector 9-C, Chandigarh, 160009, India

\section{Volume 7, Issue 2}

September 2019

ISSN 2320-7655

Copyright: [C 2019 Vidyanand S Khandagale and Rajendra Chavan] This is an Open Access article published in Issues and Ideas in Education (Issues Ideas Educ.) by Chitkara University Publications. It is published with a Creative Commons Attribution- CC-BY 4.0 International License. This license permits unrestricted use, distribution, and reproduction in any medium, provided the original author and source are credited. 